\title{
REVITALISASI NILAI BUDAYA MELALUI PERMAINAN GALAH PANJANG DI MASYARAKAT KEPULAUAN RIAU
}

\author{
Yozi Rahmadeni' dan Doni Septian ${ }^{2}$ \\ STAIN Sultan Abdurrahman Kepulauan Riau \\ 1 yozirahmadeni@gmail.com \\ 22_septian14@yahoo.com
}

\begin{abstract}
ABSTRAK
Permainan tradisional bagian dari produk budaya di masyarakat yang juga memiliki nilai-nilai budaya masyarakat itu sendiri. Artikel ini hendak menelaah nilai budaya dalam permainangalah panjang di Kepulauan Riau guna menggali nilai-nilai yang terdapat di dalamnya. Dalam kajian dini diketahui bahwa permainan ini termasuk jenis permainan kelompok laki-laki yang berupa perblombaan atau pertandingan. Sehingga nilai yang terkandung meliputi nilai kekompakan, kepemimpinan, tanggung jawab, etok kerja. Selain itu, permainan tersebut juga mampu merangsang perkembangan psikis bagi anak-anak. Dari kajian ini, revitalisasi nilai budaya daerah perlu menjadi acuan bagi pengembangan kebudayaan nasional yang sarat dengan karakter bangsa Indonesia.
\end{abstract}

\begin{abstract}
Traditional games are part of cultural products in the community that also have cultural values of the community itself. This article aims to investigate the cultural values of Galah Panjang in the Riau Islands to explore the values contained. In the early study, it is known that this game is included in the type of male group game in the form of competition. So that the values contained include the value of compactness, leadership, responsibility, and work ethic. In addition, the game can stimulate psychological development for children. From this study, the revitalization of regional cultural values needs to be a reference for the development of national culture that is full of the Indonesian characters.
\end{abstract}

Keywords: Culture, Galah Panjang, Traditional.

\section{Pendahuluan}

Indonesia merupakan Negara Kesatuan yang terdiri dari beberapa wilayah, dan berbagai macam jenis suku bangsa, adat serta budaya. ${ }^{1}$ Keragaman itu juga memiliki adat istidat berbeda, dalam bentuk fisik maupun non fisik. Satu di antara budaya itu adalah permainan tradisional dengan karakteristik masing-masing daerah. Ada juga permainan dengan nama yang berbeda tetapi banyak cara bermainnya sama. Sebab itu, permainan tradisional menjadi warisan leluhur bangsa

\footnotetext{
${ }^{1}$ Hartiningsih S. Revitalisasi Lagu Dolanan Anak Dalam Pembentukan Karakter Anak Usia Dini. Atavisme. 2015 Dec 25;18(2).hal.247.59. [http://dx.doi.org/10.24257/atavisme.v18i2.119.247259]
}

Perada, Vol. 1, No. 1, Juni 2018
Indonesia yang kaya akan budaya, adat dan tradisi yang menggambarkan corak keberagaman dan persatuan, yang tidak dimiliki oleh bangsa dan negara lain.

Kepulauan Riau (Kepri) sebagai daerah dengan yang memiliki banyak tradisi Melayu juga menimpan banyak permainan rakyat. Sebagiannya masih banyak ditemukan di daerah-daerah pulau yang masih terpencil, namun sangat jarang sekali didapati di daerah perkotaan. Padahal, permainan tradisonal itu sendiri memiliki sejarah panjang bagain dari kebudayaan masyarakat di Indonesia. ${ }^{2}$ Ada beragam jenis permainan tradisional yang

2 Lihat Ernawati Purwaningsih, Permainan Tradisional Anak: Salah Satu Khasanah Budaya yang Perlu Dilestarikan, Jurnal Jentara 2006, Vol. 1 No.1, hal. 42 
pernah hidup di masyarakat, seperti permainan khusus anak pererempuan, khusus anak lakilaki dan ada juga permainan pencampuran dari keduanya.

Hadirnya kota urban dengan karakteristik masyarakatnya yang multikultural melahirkan adaptasi dan asismilasi budaya. Sehingga, budaya yang dinilai tidak lagi sesuai dengan karakter masyarakat akan ditinggalkan, seperti halnya permainan tradisional. Pudarnya permainan tradisional diperkuat lagi dengan kenyataan perkembangan zaman era teknologi digital dan pengaruh dari globalisasi yang membuat permainan tradisional semakin terjepit hingga jarang dijumpai sekarang ini. ${ }^{3}$ Contoh permainan yang mulai jarang dijumpai di tengah masyarakat melayu Kepri yakni permainan galah panjang. Generasi anak-anak di Kepri, pada saat ini tidak lagi banyak mengenal sebagian besar jenis permainan tradisional, karena mereka saat ini lebih cenderung mengenal dan menyukai permainan instant elektronik, seperti game online mobile legend yang hanya menggunakan handphone, gadget dan sejenis alat-alat elektronik lainnya.

Para peneliti sebelumnya juga telah banyak mengungkap nilai-nilai budaya yang terdapat pada permainan tradisional. Menurut Ahimsha Putra, sebagaimana dikutip oleh Ani Lestari, bermain dan permianan memiliki fungsi sosio-kultural, yakni permainan anak-anak sebagai sebuah fenomena sosial budaya yang mempunyai makna simbolis yang memiliki efek ragawi dan maknawi. Sebab, bermain dan permainan merupakan simbol-simbol sekaligus proses simbolik yang terus-menerus dimaknai. ${ }^{4}$

${ }^{3}$ Juwairiah J. Meuen Galah: Permainan Tradisional Aceh Sebagai Media Untuk Meningkatkan Kesehatan dan Kecerdasan Anak Usia Dini. Bunayya: Jurnal Pendidikan Anak, 2017 Oct 25;1(2):119-33.hal.120

4 Theresiana Ani Lestari, Kekehan: Permianan Gasing daerah Lamongan, Jakarta: Direktorat Jenderal Nilai Budaya, Seni dan Film Kementerian Kebudayaan dan Pariwisata, 2011. Hal. 10
Pemaknaan akan terjadi apabila permainan itu dilestarikan, baik berupa kegiatan-kegiatan yang mendukung permainan maupun perkembangannya secara mandiri.

Dari latar belakang tersebut, penulis tertarik untuk melihat permainan tradisional di Kepri sebagai bagian dari upaya pelestarian nilai-nilai budaya dengan mengambil contoh pada permainan galah panjang. Permainan ini termasuk yang sudah sangat jarang dimainkan oleh masyarakat Kepri sehingga perlu juga mendapatkan perhatian untuk pelestariannya. Maka, fokus kajian ini hendak mengungkap perihal nilai budaya yang terkandung di dalam permainan galah panjang melalui metode observasi lapangan dengan pendekatan antropologi. Harus diakui bahwa penelitian antropologi budaya terhadap permainan tradisional bukan penelitian baru sehingga penelitian sebelumnya menjadi bahan rujukan untuk artikel ini.

\section{Permainan Tradisional Galah Panjang}

Permainan adalah perbuatan untuk menghibur hati baik yang mempergunakan alat ataupun tidak menggunakan alat. ${ }^{5}$ Sedangkan yang di maksud dengan tradisional ialah segala aktivitas budaya atau tradisi-tradisi yang wariskan secara turun temurun dari zaman nenek moyang, orangtua pada zaman dahulu untuk generasi pada saat ini. ${ }^{6}$ Di samping itu, nama galah panjang diambil berdasarkan beberapa penjelasan tokoh-tokoh masyarakat dan generasi-generasi sebelumnya, serta observasi atau pe-ngamatan yang penulis lakukan. Karena pada permainan ini, ditemukan salah satu garis panjang di tengahtengah lapangan yang dikuasai oleh salah satu petugas penjaga garis dan mempunyai wilayah garis penjagaan yang panjang.

${ }^{5}$ Ibid,.hal.120

${ }^{6}$ Muzdalipah I, Yulianto E, Pengembangan desain pembelajaran matematika untuk siswa SD berbasis aktivitas budaya dan permainan tradisional masyarakat Kampung Naga, Jurnal Siliwangi Seri Pendidikan. 2015 Nov 1;1(1). hal. 64

Perada, Vol. 1, No. 1, Juni 2018 
Permainan tradisional galah panjang ini adalah sejenis permainan permainan grup yang terdiri dari dua grup, dimana masing-masing grup terdiri dari 5 orang. Permainan ini biasanya dimainkan di lapangan terbuka, seperti: lapangan bola kaki, lapangan futsal, lapangan bulu tangkis dan lain sebagainya dengan acuan garis-garis yang ada, atau bisa juga dengan menggunakan lapangan empat persegi panjang, dengan ukuran panjang $15 \mathrm{~m}$ (disesuaikan dengan keadaan lingkungan atau lapangan) yang di bagi menjadi 3 bagian dengan ukuran $5 \mathrm{~m}$. Sedangkan lebar lebar 9 $\mathrm{m}$, dibagi menjadi dua bagian 4,5 m. Garis batas dari setiap bagian, biasanya diberi tanda de-ngan cat atau kapur. Selanjutnya, anggota grup yang menjaga garis batas vertikal dan garis batas horisontal, yakni: secara bergiliran atau bergantian untuk menjaga lapangan ini. ${ }^{7}$

Sesuai dengan tugas bagian untuk menjaga garis batas horizontal dalam permainan galah panjang, grup penjaga akan berusaha untuk menghalangi lawan dengan maksimal berusaha untuk melewati garis batas yang sudah ditentukan sebagai garis batas bebas, Anggota grup yang mempunyai akses untuk keseluruhan garis batas vertikal yang terletak ditengah lapangan, yakni anggota grup yang mendapatkan tugas untuk menjaga garis batas vertikal. Dalam memenangkan sebuah pertandingan galah panjang, setiap pemain harus selalu berjaga, solid, tangkas dan berlari secepat mungkin jika dibutuhkan. Permainan galah panjang bisa dikatakan sangat asyik dan menyenangkan.

Adapun jenis dan cara bermain permainan tradisional galah panjang, yakni:

1. "Lapangan dan Peralatan"

a. Lapangan
1) Bentuk : empat persegi panjang.

2) Ukuran : panjang $15 \mathrm{~m}$ (disesuaikan dengan keadaan lapangan), dan lebar $9 \mathrm{~m}$ (disesuaikan dengan keadaan lapangan).

3) Garis : garis-garis dapat dibuat dengan kapur, atau tali, atau benda lainnya yang tidak membahayakan pemain galah panjang.

a) Garis pembagi lapangan permainan dibagi menjadi dua bagian me-manjang disebut garis tengah

b) Lapangan permainan ditandai dengan garis selebar $5 \mathrm{~cm}$

${ }^{7}$ Wiasan RD, Perancangan Game Galah Asin Untuk Memperkenalkan Budaya Tradisional Jawa Barat, Jurnal. Bandung, Fakultas Seni Rupa dan Desain-Institut Teknologi Bandung (ITB). 2015 Apr 26.hal.77

Perada, Vol. 1, No. 1, Juni 2018 


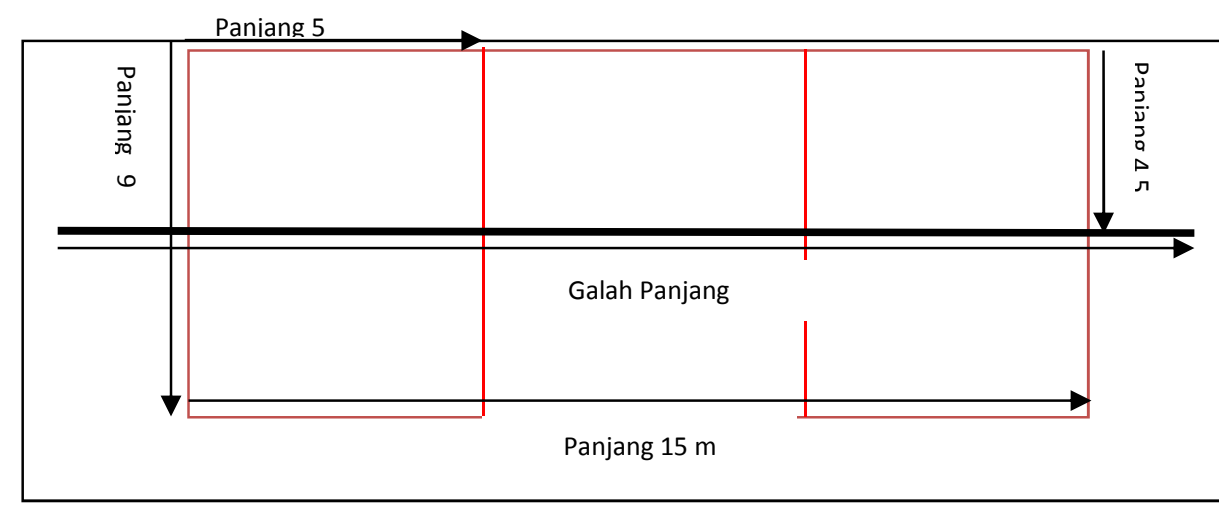

b. "Peralatan"
1) Bendera
2) Kapur/Cat Line Paper.
3) Tempat Mencatat Angka.
4) Sempritan (Peluit).
5) Jam (Stopwatch)
6) Nomor Dada.

2. "Permainan"

a. Terdiri dari dua regu masing-masing lima orang'

b. Regu putra dan regu Putri.

3. "Lamanya Permainan"

Permainan dimainkan $2 \times 20$ menit dan istirahat 5 menit'

4. "Jalannya Permainan"

a. Terlebih dahulu dilakukan undian sebelum permainan dimulai, yang menang sebagai Penyerang dan yang kalah sebagai penjaga'

b. Regu penjaga menempati kedua kaki berada di atas garisnya masingmasing, sedangkan regu penyerang siap untuk masuk menyerang."

c. Permainan dimulai setelah wasit membunyikan peluit

d. Dengan menghindari tangkapan atau sentuhan pihak penjaga, maka regu penyerang berusaha melewati garis depan.'

e. Salah satu kaki berpijak di atas garis, sedangkan kaki yang satu lagi melayang, atau dalam posisi kedua kaki berpijak di atas garis, penjaga berusaha menyentuh penyerang dengan tangan.

f. Batalnya permainan dinyatakan:

a) Apabila kedua kaki keluar garis sarnping lapangan.

b) Mengganggu jalannya permainan.

g. Pergantian (penyerang menjadi penjaga atau sebaliknya).

Pergantian diadakan oleh wasit dengan membunyikan peluit setelah :

1) Penyerang disentuh penjaga.

2) Terjadi butir 6) di atas.

3) Apabila tidak terjadi perubahan posisi selama 2 (dua) menit.

h. Penggantian pemain diadakan pada saat permainan sedang berhenti (pada saat pergantian).

i. Ketika permainan sedang berlangsung, pemain terus berlari tanpa berhenti, namun permainan akan berhenti, jika ada yang tersentuh atau tertangkap melakukan pelanggaran tata aturan permainan, maka baru permainan dihentikan oleh wasit. Kemudian wasit bisa menghentikan ketika waktu istirahat." "pemain dikatakan berhasil apabila telah melewati seluruh garis dari garis depan hingga garis belakang dan dari garis belakang sampai dengan garis depan langsung dapat melanjutkan permainan seperti semula.

j. Istirahat. 
1) "Peluit tanda istirahat dibunyikan wasitdan posisi pemain dicatat, setelah permainan berjalan 20 menit'

2) Apabila permainan babak kedua dilanjutkan posisi pemain sama seperti pada saat permainan dihentikan.

5. Nilai

a. Pemain yang telah berhasil melewati garis depan hingga garis belakang diberi nilai satu.

b. Pemain yang berhasil melewati garis belakang sampai dengan garis depan diberi nilai satu.

6. Wasit, Penjaga Garis dan Pencatat Nilai

a. 'Dipimpin oleh 2 orang wasit dan dibantu 2 orang penjaga garis dan 2 orang pencatat nilai, dalam setiap pertandingan.'

b. Kedua wasit mempunya tugas, fungsi dan wewenang yang sama.'

c. Wasit memberikan tanda dengan membunyikan peluit.'

d. Tanda diberikan dengan mengangkat bendera oleh Penjaga garis.'

e. Pencatat nilai ditempatkan di samping garis depan dan garis belakang. Nilai/angka dicatat di dua papan nilai

7. Penentuan Pemenang

Permainan ini berlangsung selama 2 × 20 menit, untuk penentuan pemenang pada permainan tradisional ini, yakni: ditetapkan atas jumlah nilai yang di dapati para pemain di dalam anggota setelah waktu berakhir."

Dari deskripsi di atas, dapat diketahui kriteria permainan yang terkandung di dalamnya, yakni berjenis perlombaan yang dilakukan secara berkelompok serta bisa dilakukan oleh anak-anak maupun orang

Perada, Vol. 1, No. 1, Juni 2018 dewasa. Permainan ini juga memerlukan ruang bermain yang besar.

\section{Manfaat Nilai yang Terkandung dalam Permainan Galah Panjang}

Galah panjang merupakan permainan tradisional yang pernah dijumpai di Kepulauan Riau pada era tahun 1990an. Permainan tradisional ini berdasarkan catatan sejarah, telah lahir sejak beberapa abad tahun yang lalu dari proses kebudayaan manusia sejak zaman dahulu yang sangat mencintai nilai-nilai kearifan lokal daerah dan lingkungan tempat mereka tinggal. Permainan tradisional tersebut mempunyai peran edukasi pembelajaran nilai yang sangat positif dan manusiawi bagi proses pembelajaran seseorang individu, terutama bagi generasi anak-anak, meskipun permainan tradisional ini banyak pihak mengata-kan sudah ketinggalan zaman dan jadul di era sekarang ini. Namun dari sisi filosofisnya permainan ini banyak hal-hal positif yang bisa dijadikan renungan dan pembelajaran di kehidupan sosial masyarakat.

Dalam permainan ini juga kandung nilainilai solidaritas perjuangan yang tinggi dan unsur nilai kebudayaan untuk dapat diwariskan kepada anak-anak sebagai generasi penerus bangsa. ${ }^{8}$ Hal tersebut mencerminkan bahwa permainan tradisional ini dapat digunakan sebagai media pembelajaran bagi generasi penerus bangsa, dalam hal ini generasi anakanak di Kepulauan Riau. Secara alamiah permainan tradisional galah panjang mampu menstimulasi dari berbagai aspek-aspek perkembangan anak yaitu: aspek pengembangan nilai-nilai etika atau moral, lingkungan, kekeluargaan, pola pikir, ketangkasan, keterampilan dan melatih

${ }^{8}$ Algiffari M. Perancangan motion graphic (bumper in) dan video dokumenter permainan tradisional Jawa Barat (analisis deskriptif permainan tradisional pada Sanggar Seni Tikukur Majalengka). Jurnal Sketsa. 2015;2(1).hal.49 
pemngembangan jiwa kreatifitas dan inovasi anak.' Permainan tradisional galah panjang mengandung nilai manfaat positif dan pemahaman etik atau moral, jika dibanding dengan permainan modern berjenis game online era saat ini.

Dari deskripsi di atas, dapat ditarik beberapa yang terkandung dalam permainan tradisional galah panjang, yakni:

a. Mampu mengembangkan keterampilan gerak dasar berlari dan reaksi

b.Mampu mengembangkan sikap sosial yang dimiliki anak untuk menyelamatkan teman nya dari garis lawan.

c. Mampu melatih kecermatan dalam menyelesaikan suatu masalah.

d.Mampu mengasah otak atau daya pikir anak

e. Mampu membantu proses perkembangan fisik dan psikis anak

f. Mampu mengembangkan kecerdasan emosi dan antar personal

g. Mampu mengembangkan logika.

h.Permainan yang murah yang tidak perlu mengeluarkan uang

i. Dapat menumbuhkan jiwa solidaritas kebersamaan dan kekompakan dalam berjuang mencapai tujuan

j. Mempererat silaturahmi sesama

Di sisi lain, yang paling terpenting nilai manfaat daripada permainan tradisional galah panjang ini, dapat membantu anak-anak saling berinteraksi secara positif, dapat mengkondisikan anak dalam mengontrol diri, mengembangkan sikap empati terhadap teman, menaati aturan, menyesuaikan diri, menghargai

\footnotetext{
9 Misbach, Ifa. 2006. Peran Permainan Tradisional Yang Bermuatan Edukatif Dalam Menyumbang Pembentukan Karakter dan Identitas Bangsa. Jakarta: Universitas Pendidikan Indonesia.

orang lain serta membuat rasa terhibur dan menyenangkan hati seseorang. ${ }^{10}$

Di samping memberikan nilai hiburan, rekreasi atau bersenang-senang, permainan tradisional ini memiliki arti tersendiri dalam menanamkan sikap, perilaku, dan keterampilan pada anak. Ada nilai-nilai luhur yang terkandung di dalamnya, seperti nilai agama, nilai edukatif, norma, dan etika yang kesemuanya itu akan ber-manfaat bagi anak ketika terjun dalam kehidupan masyarakat kelak. ${ }^{11}$ Selanjutnya, dikarenakan permainan galah panjang ini biasanya dimainkan di halaman atau di lingkungan luar dan ruangan terbuka, sehingga permainan galah panjang ini bisa menghasilkan banyak keringat dan sangat cocok untuk kesehatan bagi individu masyarakat maupun generasi anak-anak.

Permainan tradisional galah panjang ini sangat jauh berbeda sekali dengan jenis permainan modern yang kita lihat di era globalisasi sekarang ini di Provinsi Kepri, seperti: permainan game online, yang justru bermain di ruang tertutup, menggunakan peralatan yang membutuhkan biaya sangat lumayan tinggi, dan berdampak pada kurangnya mengenali lingkungan tetangga atau lingkungan sosial masyarakat, bahkan terkadang dalam permainan game online, anakanak bermain di satu tempat hanya sendiri, jikapun berdua dan bertiga, mereka tidak acuh dan tidak merespon kawan di tempat mainnya tersebut. Hal tersebut mencerminkan mereka lebih mementingkan diri sendiri, dan mengabaikan nilai budaya melayu yang kita kenal dengan nilai ramah tamah, nilai

10 Andriani T. Permainan Tradisional dalam Membentuk Karakter Anak Usia Dini. Sosial Budaya. 2012 Jun $2 ; 9(1): 121-$

36.[http://dx.doi.org/10.24014/sb.v9i1.376]

11 Nugroho Susanto, Hakikat dan Signifikansi Permainan, Jendela Olahraga 2, no. 1 (February 27, 2017). Hal. 105

Perada, Vol. 1, No. 1, Juni 2018 
solidaritas kekeluargaan, nilai kerukunan terhadap tetangga maupun lingkungan sekitar. Di samping itu permainan jenis game online ini kurang cocok untuk kesehatan, karena dalam permainannya seseorang tidak melakukan pergerakan sama sekali, hanya menggunakan jari tangan saja yang bergerak, sehingga berpengaruh kepada daya pola pikir sesorang menjadi menurun dan membuat seseorang individu tersebut untuk menjadi malas.

Berdasarkan penjelasan di atas, dapat disimpulkan bahwa permainan tradisional galah panjang ini dapat memberikan dampak yang sangat baik dalam membantu mengembangkan keterampilan emosi dan sosial individu maupun anak-anak.

\section{Hilangnya Permainan Tradional di Masyarakat}

Di Kepulauan Riau permainan tradisional galah panjang ini, terakhir masih ditemukan pada era tahun 1990an, untuk di era saat sekarang ini, sangat sulit kita menemukan permainan tersebut, apalagi sudah terbawa dengan arus globalisasi, permainan tradisional galah panjang ini bisa dikatakan punah dan hilang di tengah kehidupan masyarakat di Kepulauan Riau, khususnya terhadap anakanak saat ini, bahkan mereka tidak mengetahui dan mengenali bentuk, seperti apa dan bagaimana permainan tradisional galah panjang ini, mereka lebih cenderung mengenali kepada permainan modern. ${ }^{12}$

Hal tersebut, memang tidak bisa dipungkiri dengan kemajuan teknologiyang ada saat ini, namun setidaknya mereka harus tahu dan mengenali permainan warisan zaman yang banyak mengandung manfaat bagi fsikologis dan biologis untuk kesehatan, beretika dalam kehidupan sosial, yang paling utama dari nilai

12 Fadli Z. Membentuk Karakter Anak Dengan Olabraga Tradisional. Jurnal Ilmu Keolabragaan. 2017 Apr 12;14(2):49-56.hal.49

Perada, Vol. 1, No. 1, Juni 2018 sejarah keberada-annya. Karena jika dilihat dari proses unsur kebudayaan manusia pada zaman dahulu, mereka disini masih kental dengan nilai-nilai kearifan lokal daerah, dan mereka sangat mencintai alam beserta lingkungan tempat mereka tinggal. Sehingga banyak jenis dan bentuk permainan yang ketika itupun diambil menggunakan dari alam dan lingkungan sekitar.

Saat ini, permainan tradisional galah panjang ini ditemukan kecuali di beberapa daerah pulau yang kebanyakan dimainkan oleh anak-anak yang berasal dari pulau-pulau pesisir, itupun jika masih ada. Ada beberapa faktor yang mempengaruhi punahnya permainan tradisional, ${ }^{13}$ khususnya galah panjang di tengah kehidupan sosial masyarakat dan di kalangan anak-anak Kepulauan Riau, yakni:

a. Adanya penyempitan waktu. Seiring perubahan kurikulum belajar, semakin kompleksnya tuntutan zaman terhadap anak yang semakin membebani menyebabkan mereka sibuk dengan tuntutan di sekolahnya. Dengan banyaknya tugastugas sekolah dan tuntutan kurikulum yang semakin tinggi mengakibatkan waktu mereka tersita. Dengan demikian, mereka lebih memilih permainan yang tidak mengeluarkan banyak tenaga dan bisa dilakukan di ruang tertutup $\mathrm{d}$ cara instan menggunakan gadget, yang semestinya belum saatnya untuk mereka miliki.

b. Sarana dan tempat bermain tidak ada. Hilangnya lahan-lahan terbuka yang

13 Bandingkan dengan Darmawan O. Penanaman Budaya Anti Kekerasan Sejak Dini Pada Pendidikan Anak Melalui Kearifan Lokal Permainan Tradisional (Instill AntiViolence Culture At Early Stage of children Education Through Local Wisdom Of Traditional Games). Jurnal HAM [Internet]. Badan Penelitian dan Pengembangan Hukum dan HAM; 2016 Dec 31;7(2):111. Hal. 115 
biasa dijadikan tempat bermain dan berkreasi bagi anak-anak.. Akibat lahan tempat bermain yang tidak tersedia untuk saat ini, sehingga akhirnya, mereka anak-anak generasi saat ini, merubah pilihan permainan dari tradisional ke permainan jenis modern, seperti: mobile legend dan game online jenis lainnya.

c. Kemajuan teknologi dan derasnya arus globalisasi. Permainan tradisional ini mulai punah dan menghilang, akibat pengaruh permainan jenis modern dari luar negeri, karena permainan modern ini, 'tidak perlu menunggu orang lain untuk bermain dan ruang tempat tidak banyak digunakan.

d. Kurangnya keaktifan dalam pendataan dan pencatatan yang dilakukan oleh generasi era sekarang ini, atas jenis permainan tradisional dalam budaya masyarakat itu sendiri melalui pewaris budaya kepada generasi anak-anak di era sekarang. "Generasi era sekarang terlena oleh budaya siap saji, yang penting sudah tersedia dan siap "disantap" tanpa harus melalui proses.

e. Kurangnya perhatian, bimbingan dan pengawasan atau pemantauan pengajaran dan kebersamaan dari orang tua untuk meluangkan waktu bermain permainan tradisional terhadap anakanak, hal tersebut dikarenakan kesibukan faktor kerjaan di kantor.

\section{Urgensi Pelestarian Nilai Budaya Melalui Permainan Galah Panjang}

Permainan tradisional galah panjang pada hakikatnya mengandung banyak nilai filosofisnya, yaitu wujud dalam fungsinya sebagai suatu media untuk mengedukasikan nilai-nilai budaya pada generasi berikutnya. ${ }^{14}$

14 Nur H. Membangun Karakter Anak Melalui Permainan Anak Tradisional. Jurnal Pendidikan Karakter.
Hal ini supaya keberadaan nilai-nilai budaya yang didapati dalam kehidupan sehari-hari bisa menjadi bahan perenungan dan mencerdaskan pola pikir dalam bertindak dan bertingkah laku agar tidak betentangan dengan etika dan moral, baik agama maupun social di dalam kehidupan masyarakat. Selanjuntya, pentingnya dalam pemahaman nilai-nilai budaya melalui permainan tradisional galah panjang ini, agar terbangun jiwa solidaritas dan semangat perjuangan bersama-sama dalam mencapai sebuah tujuan.

Di samping itu, permainan tradisional ini mempunyai subtansi pembelajaran emosional pada anak, ini sangat membantu proses pengembangan fisik dan psikis anak. Di dalam kajian ilmu sosial budaya, permainan tradisional merupakan salah satu warisan budaya yang perlu dilestarikan dan dipertahankan dan dihidupkan kembali keberadaannya. Hal tersebutlah yang menjadikan pentingnya pelestarian permainan tradisional ini di dalam masyarakat umumnya dan terkhusus masyarakat Provinsi Kepulauan Riau. Dari gambaran di atas, setidaknya perlu dilakukan pelestarian sebagai upaya revitalisasi nilai-nilai budaya yang terkandung di dalamnya. Ada beberapa langkah yang bisa diupayakan untuk pelestarian permainan tradisional.

Pertama, dengan cara memperkenalkan, menerapkan dan memasukkan kembali permainan tradisional tersebut sebagai satu aktifitas kurikulum pembelajaran di tingkat sekolah baik formal maupun informal atau ke dalam mata kuliah perguruan tinggi.

Kedua, adanya kerjasama dari berbagai pihak dan juga lembaga dalam hal ini, LSM, OKP, LAM dan pemerintah supaya menggiatkan kembali permainan tradisional ini melalui berbagai macam kebijakannya.

\begin{tabular}{llcl}
\hline 2013 & (1). & hal. & 89. \\
[http://dx.doi.org/10.21831/jpk.v0i1.1290] &
\end{tabular}

Perada, Vol. 1, No. 1, Juni 2018 
Ketiga, orangtua hendaknya memperkenalkan dan memainkan permainan tradisional galah panjang ini bersama anak. Dengan dilakukan demikian, setidaknya si anak secara tidak langsung bisa menimbulkan stimulus rangsangan rasa ingin tahu itu sangat tinggi dari kedekatan orangtua dalam membimbing dan mengarahkan gambaran permainan yang mengandung nilai ke arah positif untuk kemajuan dan perkembangan anak.

Keempat, upaya penyadaran kepada pihak-pihak terkait khususnya orang tua akan dampak negatid game online bagi generasi anakanak. Orangtua mempunyai peran penting untuk lebih tahu terkait perkembangan anaknya, dengan cara menasehati terhadap si anaknya, kalau si anak boleh bermain game, namun harus menunggu usia selayaknya, dan alangkah lebih baiknya memperkenalkan kepada anak tentang warisan sejarah permainan-permainan tradisional dari hasil kebudayaan setempat, agar ketika usia anak menanjak, minimal sudah ada sedikit gambaran buat si anak sebagai wawasan pengembangan karakternya, untuk membangkitkan motivasi jiwa si anak supaya menjaga, merawat dan melestarikan kecintaannya pada alam dan lingkungan sekitar.

Dengan beberapa upaya-upaya dan langkah-langkah yang dilakukan tersebut, sudah tentu dapat melestarikan dan menghidupkan kembali keberadaan permainan tradisional budaya di masa lalu ini, menjadi permainan yang gemilang pada kalangan masyarakat dan generasi anak bangsa kita di masa saat sekarang dan mendatang, dalam hal ini Provinsi Kepulauan Riau. Hal tersebut tentu saja tidak terlepas dengan partisipasi dan kerjasama dari semua pihak seperti yang penulis sebutkan di atas, beberapa langkah dan upaya ini akan dapat mempopularkan kembali nilai warisan budaya bangsa kita sampai kapanpun. Semua pihak ini hendaklah berganding bahu dan tangan untuk pelestarian, menghidupkan dan mempopularkan kembali per-mainan galah panjang, permainan galah panjang ini merupakan nilai warisan budaya bangsa kita, yang tidak ternilai harganya, jika di bandingkan dengan uang. Seperti kata pepatah "bulat air kerana pembetung, bulat manusia kerana mufakat" dan "jika tidak ada permainan tradisional warisan berzaman ini hanya tinggal nama sahaja pada suatu masa nanti”.

\section{Kesimpulan}

Permainan tradisional merupakan bagian dari khazanah budaya masyarakat yang muncul bersaman dengan proses kebudayaannya. Jenisnya, bisa berupa permainan sebagai bentuk hiburan dan permainan yang bersifat perlombaan. Permainan galah panjang termasuk permainan yang besifat perlombaan dan dilakukan secara kolektif. Dari gambaran di atas, dapati juga disimpulkan bahwa permainan ini mengandung nilai-nilai budaya yang tumbuh dalam masyarakat. Beberapa nilai yang terkandung di dalamnya, berupa nilai edukasi, kepemimpinan, kekompakan, mampu mengembang kemampuan fisik dan psikis bila dimainkan oleh anak-anak.

Dari gambaran di atas, dapat disimpulkan juga perihal pentingnya permainan tradisional untuk dilestarikan sehingga memerlukan kajian lebih lanjut dari berbagai asepek dan perspektif lainnya. Sebagaimana diketahui, permainan tradisional sering menjadi permainan yang banyak digemari anak dan menjadi pilihan alternatif olah raga. Selain itu, perlu dilakukan langkahlangkah revitalisai permainan tradisional agar tidak ketinggalan zaman dan punah.] 


\section{Daftar Rujukan}

Algiffari M. Perancangan motion graphic (bumper in) dan video dokumenter permainan tradisional Jawa Barat (analisis deskriptif permainan tradisional pada Sanggar Seni Tikukur Majalengka). Jurnal Sketsa. 2015;2(1).

Andriani T. Permainan Tradisional dalam Membentuk Karakter Anak Usia Dini. Sosial Budaya. 2012 Jun 2;9(1):121-36. [http://dx.doi.org/10.24014/sb.v9i1.376].

Fadli Z. Membentuk Karakter Anak Dengan Olahraga Tradisional. Jurnal Ilmu Keolahragaan. 2017 Apr 12;14(2):49-56.

Hartiningsih S. Revitalisasi Lagu Dolanan Anak Dalam Pembentukan Karakter Anak Usia Dini. Atavisme. 2015 Dec 25;18(2). [http://dx.doi.org/10.24257/atavisme.v18i2.119.247-259]

Juwairiah J. Meuen Galah: Permainan Tradisional Aceb Sebagai Media Untuk Meningkatkan Kesehatan dan Kecerdasan Anak Usia Dini. Bunayya: Jurnal Pendidikan Anak. 2017 Oct 25;1(2):119-33.

Misbach, Ifa. 2006. Peran Permainan Tradisional Yang Bermuatan Edukatif Dalam Menyumbang Pembentukan Karakter dan Identitas Bangsa. Jakarta: Universitas Pendidikan Indonesia.

Muzdalipah I, Yulianto E. Pengembangan desain pembelajaran matematika untuk siswa SD berbasis aktivitas budaya dan permainan tradisional masyarakat Kampung Naga. Jurnal Siliwangi Seri Pendidikan. 2015 Nov 1;1(1).

Nur H. Membangun Karakter Anak Melalui Permainan Anak Tradisional. Jurnal Pendidikan Karakter. 2013(1). [http://dx.doi.org/10.21831/jpk.v0i1.1290]

Wiasan RD. Perancangan Game Galah Asin Untuk. Memperkenalkan Budaya Tradisional Jawa Barat. Jurnal. Bandung: Fakultas Seni Rupa dan Desain-Institut Teknologi Bandung (ITB). 2015

Susanto, Nugroho, Hakikat dan Signifikansi Permainan, Jendela Olahraga 2, no. 1 (February 27, 2017). [http://doi:10.26877/jo.v2i1.1287]

Darmawan O, Penanaman Budaya Anti Kekerasan Sejak Dini Pada Pendidikan Anak Melalui Kearifan Lokal Permainan Tradisional (Instill Anti-Violence Culture At Early Stage of children Education Through Local Wisdom Of Traditional Games). Jurnal HAM [Internet]. Badan Penelitian dan Pengembangan Hukum dan HAM; 2016 Dec 31;7(2):111. [http://dx.doi.org/10.30641/ham.2016.7.111-124 